\title{
RESPONSE OF ORGANIC MANURES ON POST HARVEST AND SOIL NUTRIENT RESTORATION ON CAULIFLOWER PRODUCTION
}

\author{
M. Basnet ${ }^{1}$ S.M. Shakya ${ }^{2}$ B.R. Baral ${ }^{3}$
}

\begin{abstract}
This study was conducted at Ilam Municipality-2, Nepal to determine the response of organic manures on post harvest and nutrient restorative effect of cauliflower. Five manures, viz., bansoon, mustard oil cake, poultry manure, farmyard manure, and vermi-compost were evaluated. The postharvest losses, vitamin C content and soil nutrient restorative behavior were significantly highest with vermi-compost as compared to other manures. The maximum vitamin $C$ content of $10.92 \mathrm{mg} / 100 \mathrm{gm}$ was found with vermi-compost whereas the lowest of $9.66 \mathrm{mg} / 100 \mathrm{gm}$ was found at farmyard manure. Moreover, the physiological losses were found to be least with vermi compost and the most with bansoon manure. Moreover, the restorative properties i.e. $\mathrm{pH}$, $N, P, K$ and organic \%age were found to be significantly highest with vermi-compost as compared to other organic manures. This study concludes that vermi compost increases vitamin $C$ content, postharvest longevity and improvement of physical and chemical properties of the soil.
\end{abstract}

Key words: Organic manure, post harvest, soil nutrient restoration

\section{INTRODUCTION}

Cauliflower (Brassica oleracea L. var. botrytis) belongs to the family Brassicaceae. The Mediterranean region is considered as the center of origin of cauliflower (Lal, 1993). Cauliflower is consumed at large volume as a high nutritive fresh vegetable worldwide (Oowen and Grubbe, 1977). It contains diverse nutrients, vitamins and minerals comprised of vitamin $A, B_{1}, C$, protein, fat, carbohydrates, potassium, phosphorus, sulphur, iron, copper, carotenoids, and B-carotene (Singh and Singh, 1994). Moreover, it has also medicinal values and therapeutic effects as it contains high concentration of glucothiocyanate, which is effective in the inhibition of carcinogenesis (McDonald, 1971).

Cauliflower requires considerable amount of nutrients for growth and development (Chatterjee, 1993; Thakur et al.,1991). It can be grown on a wide range of soil rich in nutrients, adequate soil moisture and on a neutral to slightly acid soils i.e. at pH 6.0 to 7.0. Now a days, in the name of increasing production, haphazard use of chemical fertilizers has deteriorated the fertility status of Nepalese soil (Tripathi et al., 2005). In addition, ecological imbalance, severe health hazards on humans and animals, loss of biodiversity are emerging as major problems for chemical based agriculture production (Khanal and Manandhar, 2004). This situation has aggravated the situation of poor people being non-affordable and unreliable high cost external inputs.

Improvement and maintenance of soil physical, chemical and biological properties are the key features in successful organic vegetable production system (Subedi and Regmi, 2006). In this sense, organic manure is the sustainable option as it increases water-holding capacity of soil; improves soil texture and structure. Organic manure contains a very high population of bacteria, actinomycetes and fungi so that microbiological activity get increased that resulted into increased mineralization

1 Manoj Basnet, Assistant Professor, Institute of Agriculture and Animal Science, TU, manoj@iaas.edu.np

2 Dr. Shanta Man Shakya, Professor, Institute of Agriculture and Animal Science, TU.

3 Bandhu Raj Baral, Senior Scientist, Nepal Agriculture Research Council. 
of organic nitrogen and thus nutrients become available to the plants (Shrestha, 2008; Gupta et al., 2000; Carpenter et al., 2000). Similarly, they provide humic substances, higher cation exchange capacity and heat absorbing capacity that enhances the utilization of nutrients by plants with increasing organic carbon content of the soil (Gaur, 1992).

Physiological loss of cauliflower curd is associated with the losses by weight and quality of produce. Further, loss due to the effect of disease development also implies significant loss during storage. Similarly, chemical changes are associated with the post harvest quality of curds and these are also vulnerable to changes with physical losses, but it depends upon the several factors such as storage environments and pre harvest factors. The organic manures increased the post harvest longevity in terms of spoilage and weight loss is due to the availability of micronutrients which strengthened the cellular and sub-cellular parts of the curd (Bhattarai and Budhathoki, 2005).

\section{OBJECTIVES}

- To determine the response of organic manures on post harvest quality on cauliflower production

- To determine the soil nutrient restorative effect of organic manures on cauliflower production.

\section{METHODOLOGY}

The experiment was conducted at Ilam Municipality-2, Ilam during 2015 with the financial support from Univeristy Grant Commission (UGC)/Tribhuvan University. Five common organic manures i.e. bansoon (14.4 mt ha-1), poultry manure (14.4 mt ha-1), mustard oil cake (16.3 mt ha-1), farmyard manure (8 $\mathrm{mt} \mathrm{ha-1)}$, and vermi-compost (11.4 mt ha-1) were selected and were laid out in Randomized Complete Block Design (RCBD) and replicated four times. The treatments and their dose were selected based on the farmer's practices at llam district. The crops were planted with the spacing of $60 \mathrm{~cm} * 60 \mathrm{~cm}$ on each plot having 5 rows with 4 plants per row on an area of $7.2 \mathrm{~m}^{2}$. There were 20 plants in each plot among which 14 plants were considered as boarder plants and 6 inner plants as observational plant.

After harvesting the observational plant, the testing parameters i.e. physiological losses (weight loss and spoilage), vitamin c content and the soil properties were sampled.

\section{DETERMINATION OF VITAMIN C CONTENT}

Firstly, $5 \mathrm{ml}$ of working standard solution prepared by dissolving fresh cauliflower curd sample. Then, $10 \mathrm{ml}$ of $4 \%$ oxalic acid added to the standard solution, and titrated against the dye ( $\mathrm{V}, \mathrm{ml})$ until the appearance of pink color (end-point), thus the amount of dye consumed is equivalent to the amount of ascorbic acid. To make known volume $(100 \mathrm{ml}), 0.5-5 \mathrm{~g}$ sample was extracted on $4 \%$ oxalic acid and centrifuged. Then, $5 \mathrm{ml}$ of supernatant was pipette out and $10 \mathrm{ml}$ of $4 \%$ oxalic acid added. It was titrated against the dye $\left(\mathrm{V}_{2} \mathrm{ml}\right)$ until pink color develops. Finally, amount of ascorbic acid (vitamin C) calculated with the following formula:

$$
\begin{aligned}
& \text { Amount of ascorbic acid }(\mathrm{mg} / 100 \mathrm{gm} \text { of curd })=\frac{1000.5 \mathrm{mg} \times \mathrm{V}_{2} \mathrm{ml} \times 100 \mathrm{ml}}{\mathrm{V}_{1} \mathrm{ml} \times 5 \mathrm{ml} \times \text { wt. of sample }} \\
& \text { Where, } \quad \mathrm{V}_{1}=\text { Titrated volume of standard solution against dye } \\
& \quad \mathrm{V}_{2}=\text { Titrated volume of sample solution against dye }
\end{aligned}
$$




\section{MEASUREMENT OF PHYSIOLOGICAL AND SPOILAGE LOSS}

\section{Physiological loss}

The physiological loss by weight (PLW) of randomly selected five sample curds with and without their jacket leaves was examined by keeping them in normal room condition $\left(20 \pm 3{ }^{\circ} \mathrm{C}\right.$ temperature and $60 \pm 5 \%$ relative humidity) for a week. PLW calculated by using following formula:

$$
\text { PLW }(\%)=\frac{\text { Initial weight of sample }- \text { Final weight of sample }}{\times 100}
$$

\section{Spoilage loss}

The spoilage loss of randomly selected five sample curds with and without their jacket leaves was examined by keeping them in ordinary room condition $\left(20 \pm 3^{\circ} \mathrm{C}\right.$ temperature and $60 \pm 5 \%$ relative humidity) for a week. It was by using following formula:

$$
\text { Spoilage loss }(\%)=\frac{\text { Weight of spoiled curds }}{\text { Original weight of curds }} \times 100
$$

\section{DETERMINATION OF SOIL PROPERTIES}

Soil samples from four replication blocks of the experimental field were analyzed before and after experiment conduction at Soil Testing Laboratory, Jhumka, and Sunsari.

The data obtained were entered into the MS Excel, analyzed and interpreted through MSTAT.

\section{RESULT AND DISCUSSION}

\section{VITAMIN C CONTENT}

The vitamin $C$ content was significantly highest with vermi-compost $(10.92 \mathrm{mg} / 100 \mathrm{gm})$ followed by mustard oil cake $(10.60 \mathrm{mg} / 100 \mathrm{gm})$, while the lowest vitamin C content was recorded at farmyard manure $(9.66 \mathrm{mg} / 100 \mathrm{gm})$.

Subbiah (1994) found that the easily available organic manure increased vitamin C and crude protein content of cauliflower curds. The highest vitamin $C$ content with vermi-compost could be due to the essential elements present in it which enhanced vitamin $C$ synthesis. Organic crops contained significantly more vitamin $C$, iron, magnesium, phosphorus, substantially significant mineral with lower amounts of some heavy metals and significantly less nitrates than conventional crops (Carl and Winter, 2006).

Effect of different organic manures on vitamin C content of cauliflower curd

\begin{tabular}{lc}
\hline Treatments & Vitamin C content $(\mathrm{mg} / \mathbf{1 0 0 g m})$ \\
\hline Bansoon & $10.08 \mathrm{ab}$ \\
Mustard Oil Cake & $10.60 \mathrm{a}$ \\
Poultry Manure & $9.69 \mathrm{~b}$ \\
Farmyard Manure & $9.66 \mathrm{~b}$
\end{tabular}




$\begin{array}{lc}\text { F test } & * \\ \text { LSD } 0.05 & 0.828 \\ \text { SEm } \pm & 0.269 \\ \text { CV } \% & 5.3\end{array}$

* Denotes significantly different at $P<0.05$. Means within column followed by the same letter are nonsignificantly different at $5 \%$ level.

\section{PHYSIOLOGICAL LOSS}

\section{Weight loss and spoilage loss}

Physiological loss by weight without jacket leaves was highest with the application of bansoon $(48.98 \%)$ and lowest with vermi-compost $(33.81 \%)$. Similarly, the physiological weight loss of curd with jacket leaves was highest at bansoon $(30.09 \%)$ and lowest with the application of vermicompost $(24.45 \%)$. Similarly, the minimum spoilage loss along with and without jacket leaves was recorded to be $40.66 \%$ and $42.95 \%$ respectively with vermi-compost application whereas the maximum spoilage loss along with and without jacket leaves was found to be $49.55 \%$ and $61.79 \%$ respectively with bansoon application.

Effect of organic manures on physiological loss by weight and spoilage loss of curds

\begin{tabular}{l|cccc}
\hline \multirow{2}{*}{ Treatments } & \multicolumn{2}{|c}{ Physiological loss in weight (\%) } & \multicolumn{2}{c}{ Spoilage loss (\%) } \\
\cline { 2 - 5 } & $\begin{array}{c}\text { (without jacket } \\
\text { leaves) }\end{array}$ & $\begin{array}{c}\text { (with jacket } \\
\text { leaves) }\end{array}$ & $\begin{array}{c}\text { (without jacket } \\
\text { leaves) }\end{array}$ & $\begin{array}{c}\text { (with jacket } \\
\text { leaves) }\end{array}$ \\
\hline Bonsoon & $48.98 \mathrm{a}$ & $30.09 \mathrm{a}$ & $61.79 \mathrm{a}$ & $49.55 \mathrm{a}$ \\
Mustard cake & $37.49 \mathrm{~d}$ & $26.41 \mathrm{c}$ & $48.02 \mathrm{~d}$ & $40.94 \mathrm{c}$ \\
Poultry Manure & $41.00 \mathrm{c}$ & $28.60 \mathrm{~b}$ & $53.77 \mathrm{c}$ & $41.46 \mathrm{c}$ \\
Farmyard Manure & $44.87 \mathrm{~b}$ & $28.89 \mathrm{~b}$ & $59.12 \mathrm{~b}$ & $45.50 \mathrm{~b}$ \\
Vermi-compost & $33.81 \mathrm{e}$ & $24.45 \mathrm{~d}$ & $42.95 \mathrm{e}$ & $40.66 \mathrm{c}$ \\
\hline F test & $* *$ & $* *$ & $* *$ & $* *$ \\
LSD 0.05 & 0.857 & 0.684 & 0.5017 & 1.019 \\
SEm \pm & 0.278 & 0.2220 & 0.1628 & 0.331 \\
CV $\%$ & 1.3 & 1.6 & 6 & 1.5 \\
\hline
\end{tabular}

** and denotes significantly different at $\mathrm{P}<.001$ and $\mathrm{P}<0.05$ respectively. Means within column followed by the same letter are non-significantly different at $5 \%$ level.

\section{EFFECT OF ORGANIC MANURES ON SOIL PROPERTIES AFTER HARVEST}

The following table showed the chemical properties viz., $\mathrm{pH}$, organic matter (OM), available nitrogen $(\mathrm{N})$, phosphorus $\left(\mathrm{P}_{2} \mathrm{O}_{5}\right.$ and potash $\left(\mathrm{K}_{2} \mathrm{O}\right)$ of experimental soil after crop harvest. The effect of different organic manures was found to be significant on soil $\mathrm{pH}$, organic matter, $\mathrm{N}_{2} \mathrm{P}_{2} \mathrm{O}_{5}$ and $\mathrm{K}_{2} \mathrm{O}$. The highest soil restorative effect i.e. organic matter $(3.92 \%), \mathrm{N}(0.19 \%), \mathrm{P}_{2} \mathrm{O}_{5}(352.64 \mathrm{~kg}$ ha-1) and 
$\mathrm{K}_{2} \mathrm{O}$ (401.29 kg ha-1) was observed on the vermi-compost applied field. Similarly, the amendment of $\mathrm{pH}$ level towards normal level was found to be significant (6.67) with vermi- compost as compared to other organic manures.

Effect of organic manures on soil properties after harvest

\begin{tabular}{lccccc}
\hline \multicolumn{1}{c}{ Treatments } & $\mathrm{pH}$ & $\mathrm{OM} \%$ & $\mathrm{~N} \%$ & $\mathrm{P}_{2} \mathrm{O}_{5}\left(\mathrm{~kg} \mathrm{ha}^{-1}\right)$ & $\mathrm{K}_{2} \mathrm{O}\left(\mathrm{kg} \mathrm{ha}^{-1}\right)$ \\
\hline Bansoon & $5.54 \mathrm{ab}$ & $3.65 \mathrm{bc}$ & $0.174 \mathrm{ab}$ & $321.68 \mathrm{c}$ & $310.10 \mathrm{c}$ \\
Mustard oil cake & $5.68 \mathrm{ab}$ & $3.72 \mathrm{~b}$ & $0.175 \mathrm{ab}$ & $319.02 \mathrm{~d}$ & $345.21 \mathrm{~b}$ \\
Poultry manure & $5.06 \mathrm{~b}$ & $3.73 \mathrm{~b}$ & $0.177 \mathrm{ab}$ & $319.80 \mathrm{~d}$ & $345.43 \mathrm{~b}$ \\
Farmyard manure & $5.66 \mathrm{ab}$ & $3.62 \mathrm{c}$ & $0.170 \mathrm{~b}$ & $341.10 \mathrm{~b}$ & $288.61 \mathrm{~d}$ \\
Vermi-compost & $6.67 \mathrm{a}$ & $3.92 \mathrm{a}$ & $0.19 \mathrm{a}$ & $352.64 \mathrm{a}$ & $401.29 \mathrm{a}$ \\
\hline F test & $*$ & $* *$ & $*$ & $* *$ & $* *$ \\
LSD 0.05 & 0.3894 & 0.0905 & 0.0073 & 1.172 & 1.629 \\
SEm \pm & 0.1264 & 0.0294 & 0.00238 & 0.380 & 0.529 \\
CV \% & 4.4 & 1.6 & 2.7 & 0.2 & 0.3 \\
\hline
\end{tabular}

** and denotes significantly different at $\mathrm{P}<.001$ and $\mathrm{P}<0.05$ respectively. Means within column followed by the same letter are non-significantly different at $5 \%$ level.

\section{CONCLUSION}

It is found that vermi-compost has a significant effect on physiological losses i.e. lowest weight and spoilage loss, highest vitamin $\mathrm{C}$ content and highest soil nutrient restorative properties as compared to other manures. Thus, it is recommended to use vermi-compost during organic cauliflower production.

\section{REFERENCES}

Bhattarai, D.R. and Budhathoki, K., 2005. Effect of organic manures on pre and post harvest physiology and consumers' acceptability of cauliflower (Brassica oleracea var. botrytis). Nepal Journal of Science and Technology 6: 11- 14.

Carl, K.S. and Winter, F.D., 2006. Nutritional quality of organic versus conventional fruits, vegetables and grains. Journal of Food Science 71 (9): 117.

Carpenter B.L., Kennedy, A.C. and Reganold, J.P., 2000. Organic and biodynamic management: Effect on soil biology. Soil Science Society of American Journal 64 (5): 1651-1659.

Chatterjee, S.S., 1993. Cole Crops. In: Bose, T.K. and Som, M.G., (Eds.). Vegetable Crops in India: Naya Prakash, Calcutta.

Fritz, P.D. and Weichmonn, K.R., 1980. Vitamin c in stored cauliflower. Horticultural Abstracts 50 (4): 217.

Gaur, A.C., 1992.Bulky organic manure and crop residues.In: Tendon, H.L.S., (ed) Fertilizers, organic manure, recyclable wastes and biofertilizers: Fertilizers Development and Consultation organization, New Delhi 36-51. 
Gupta, R.K., Arora, B.R. Sharma, K.N. and Ahluwalia, S.K., 2000. Influence of biogas slurry and farmyard manure application on the changes in soil fertility under rice-wheat sequence. Journal of the Indian Society of Soil Science. 48(3): 500-505.

Khanal, M.P. and Manandhar, R., 2004. Chemical fertilizers: Environmentally friendly or harmful. Gender Equity and Environment Division: Ministry of Agriculture and Cooperatives, Government of Nepal, Kathmandu.

Lal, G., 1993. Agro-techniques for cole crops. In: Chadha, K.L. and Paren, O.P. (Eds.): Advances in Horticulture (4): 503-521. Malhotra publishing house, New Delhi.

McDonald, L., 1971. Garden vegetables: the story of vegetables. Thomas Nelson Inc., New York.

Oowen, H. A. and Grubben, G.J.H., 1977.Tropical vegetables in human nutrition.Department of Agriculture Research, Koninklijk Institute Voorde Tropen, Amsterdam.

Shrestha, Y. M., 2008. Response of nasabike manure and agri-medicine in relation to organic cabbage production in Ilam, Nepal. Masters thesis submitted to Institute of Agriculture and Animal Science (IAAS), Agriculture (Ecology), Rampur, Chitwan.

Singh, B. and Singh, K., 1994. Effect of nitrogen and spacing of yield and economics of seed production in mid season cauliflower. Vegetable Science 21 (1): 32 - 35.

Subbaiah, K., 1994. Studies on the effect of nitrogen and Azospirillum on okra. South Indian Horticulture 39: 37-44.

Subedi, B. and Remi, H.R., 2006. Technological Development in Organic Vegetable Production System in Nepal. In: Proceeding of a First National Workshop on Organic Farming, 12-14 June 2006 (Baishakh 28-30, 2063), Kirtipur, Kathmandu. Directorate of Agriculture Extension, Directorate of Vegetable Development, and District Agricultural Development Office, Kathmandu 43-48

Thakur, O.P., Sharma, P.P. and Singh, K.K., 1991. Effect of nitrogen and phosphorus with and without boron on curd yield and stalk rot incidence in cauliflower. Vegetable Science 18: 115-121.

Tripathi, B.P., Gardener, R., Mowdeslay, K.J., Acharya, G.P. and Sah, R.P., 2005. Soil erosion and fertility losses in the western hills of Nepal: An overview. Sustainable Soil Management Program/ Helvetas Kathmandu. Nepal. 